University of Montana

ScholarWorks at University of Montana

$6-1980$

\title{
Wilderness Recreation Experiences: The Rawah Case
}

Perry J. Brown

University of Montana - Missoula, perry.brown@umontana.edu

Glenn E. Haas

Colorado State University - Fort Collins

Follow this and additional works at: https://scholarworks.umt.edu/forest_pubs

Part of the Forest Management Commons

Let us know how access to this document benefits you.

\section{Recommended Citation}

Brown, Perry J. and Haas, Glenn E., "Wilderness Recreation Experiences: The Rawah Case" (1980). Forest Management Faculty Publications. 37.

https://scholarworks.umt.edu/forest_pubs/37

This Article is brought to you for free and open access by the Forest Management at ScholarWorks at University of Montana. It has been accepted for inclusion in Forest Management Faculty Publications by an authorized administrator of ScholarWorks at University of Montana. For more information, please contact scholarworks@mso.umt.edu. 


\title{
Wilderness Recreation Experiences: The Rawah Case ${ }^{1}$
}

\section{Perry J. Brown and Glenn E. Haas}

\begin{abstract}
This research focused on defining wilderness recreation experiences in terms of the psychological outcomes sought by the recreational users of the Rawah Wilderness in Colorado. Information on the outcomes was used to type users so that groups seeking different experiences could be identified. From a sample of 264 people, there were five types of wilderness recreation experiences identified.

Use of information on the psychological outcomes sought by recreationists and on the types of recreationists pursuing specific activity and experience opportunities is discussed. Such information would aid in the devleopment of more specific, quantifiable, and evaluative management objectives; could provide a basis for developing recreation inventories, selecting management tools and techniques, and in developing visitor information packages; and might aid in the differential economic valuation of wilderness recreation activity and experience opportunities.
\end{abstract}

KEYWORDS: Wilderness Recreation, recreation experiences, recreational outcomes, recreationist behavior.

AUTHORS: Perry J. Brown is Professor and Head, Department of Resource Recreation Management, Oregon State University, Corvallis. Glenn E. Haas is Research Associate, Department of Recreation Resources, Colorado State University, Fort Collins.

Journal of Leisure Research, Volume 12, Number 3, pp.229-241. Copyright 9980 by the National Recreation and Park Association.

ecreation planning, management, and research have often suffered from a lack of understanding of what is being demanded by recreationists. Traditionally, demand for recreation has been operationalized as demand for

1 Data collection for this paper was supported by the McIntire-Stennis Forestry Research Program, USDA. In developing this paper the authors relied heavily upon insights and ideas developed in working with Dr. B. L. Driver, Recreation Project Leader at the Rocky Mountain Forest and Range Experiment Station, Fort Collins, Colorado. 
activities such as hiking, camping, and fishing. In the research discussed here, the recreational activity is viewed as a means to a recreational end, with the end being the gaining of desired psychological outcomes. We refer to sets of these desired outcomes as the desired recreational experience (Driver and Brown 1978). It is our contention, and that of our colleagues, that without a clear specification of the demanded recreational experiences it is difficult to value recreation, adequately plan for it, or to manage the recreation resources (see Driver and Tocher 1970; Brown et al. 1973; Hendee 1974; Driver and Brown 1975 and 1978).

In the past, most recreation resource planning and management decisions have been guided by informed intuitions about recreationists. Unfortunately, previous research has indicated that these intuitions about recreationist desires often differ from a recreationist's preferences and behavior (Lucas 1964; Hendee and Harris 1970; Clark et al. 1971; and Peterson 1974a). Managers' assumptions about what is desired have not necessarily reflected consumer preferences. To partially remedy this mismatch, some of our research, like that reported here, is part of a program designed to help managers gain better perceptions of user desires. Specifically in this paper we report a study of users of the Rawah Wilderness.

Our approach to consumer preference evaluation stems from work in expectancy theory of industrial (e.g., Lawler 1973) and motivational (e.g., Atkinson 1957) psychology. Within this framework we are interested in the kinds of outcomes desired by recreationists from participating in activities and in the psychological values attached to different outcomes. We assume that if managers know what outcomes people desire, then management can attempt to meet those desires where it is appropriate to do so within other constraints. Consistent with this assumption, managers might set specific objectives to provide opportunities for meeting specific outcomes such as experiencing nature, affiliating with others, taking risks, and getting away from oppressive environments. Then management might strive to meet those objectives.

\section{Methods}

To define the recreation experience desired by users of the Rawah Wilderness, a mail questionnaire was sent to a sample of summer (1975) visitors. ${ }^{2}$ The Rawah Wilderness encompasses 17,000 acres, is a two hours drive west of Fort Collins, Colorado; and is approximately a three hours drive from Denver.

The questionnaire contained three parts: (1) socioeconomic questions, (2) questions concerning the visitor's trip, and (3) scaled measures of psychological outcomes. Seventy-one psychological outcome items provided the means for defining wilderness recreation experiences. The development of these outcome items was via informal interviews with wilderness users and a review of

2 U. S. Forest Service statistics indicate that over 90 percent of Rawah use occurs during the summer months. 
literature. There have been several previous papers reporting on experiences of different activity participants (Hendee et al. 1968; Catton 1969; Shafer and Mietz 1969; Sewell and Rostron 1970; Knopf et al. 1973; Potter et al. 1973; Stankey et al. 1973; Peterson 1974b; Driver and Knopf 1976; Driver 1976; Brown et al. 19773).

The psychological outcomes were scaled by asking, "How did each of the following items add to or detract from your wilderness experience"? A bipolar 9-point modified Likert response format was used. The responses were anchored by the statements "most strongly adds" and "most strongly detracts."

The sample frame for this study involved the trail registration cards filled out by wilderness users during the summer of 1975.4 Names and addresses were collected on the cards. A systematic sample of 300 names and addresses was drawn to provide a proportional representation of day users and overnight users as well as wilderness visitors in June, July, and August. An initial questionnaire mailing and two follow-ups were made during the winter of 1976.

The data were analyzed using several subroutines of the BC-TRY cluster analysis system (Tryon and Bailey 1970). The variable clustering subroutine permits empirical grouping, across all respondents, of the psychological outcome items into outcome domains. The assumption is that the items in a single cluster relate to the same content theme. 5

Next, respondents were clustered to identify those groups of respondents valuing the outcome clusters similarly. The object clustering subroutine in the BY-TRY system uses a Euclidean distance measure to identify types. The clusters of people reflect the different recreation experiences that are desired by different groups of users. 6

3 Based upon work conducted over the last 10 years, B. L. Driver (Rocky Mountain Forest and Range Experiment Station) and P. J. Brown (Oregon State University) presently have 42 psychological outcome scales which can be grouped in 20 domains. These scales have been employed in studies of participants in many different activities. In this study, items from the eight outcome domains judged most relevant to wilderness recreation were used.

4 In a 1970 study the trail register compliance rate for Rawah Wilderness users was 89 percent (James and Schreuder 1972).

5 See Tryon (1959), Tryon and Bailey (1970), and Hautaluoma and Brown (1978) for more detail about the clustering method used in this analysis and how it compares to other factor analysis methods. Key-cluster factoring was used in this study. It defines a dimension, or factor, as a subset of the variables. The subset is composed of the group of variables most collinear (highly related) to a "pivot" variable. The pivot variable is selected on the basis of its pattern of intercorrelations with the entire variable set.

6 Since the variable clusters are based on correlations and the object clusters on mean scores and standard deviations of the variable clusters, we believe that the independence problem which might exist between outcomes and user clusters is ameliorated. Further research involving double-cross validation procédures and a larger sample size is recommended to assess this potential problem. 
A final stage of the analysis involved discovering additional (e.g., socioeconomic) characteristics of the groups of recreationists identified through object clustering and utilized the 4 CAST subroutine in the BC-TRY system. Briefly, this subroutine applies a Monte Carlo samplign procedure to create empirical distributions of selected variables (e.g., socioeconomic) against which to compare the user group mean (identified by the object clustering) on the same selected variable. From this analysis it was possible to determine the probability of the user group mean for each selected variable being smaller, equal to, or larger than the overall sample mean of the population.

In the following section we identify psychological outcomes, define the clusters of people, and provide a description of the clusters of people based on several selected variables.

\section{Results}

Of the 300 questionnaires mailed to Rawah Wilderness users, 164 (88 percent) usable questionnnaires were returned. Of the 71 scaled outcome items, 9 were not assigned to any cluster because each had a communality with the remaining items of less than .20. The remaining 62 outcome items clustered into eight domains. Because some of the items did not increase the reliability coefficient of the clusters, correlate $(r>.40)$ with other outcome items, or intuitively relate to the other outcome items, only 40 items were kept in the clusters and are shown in Table 1.7 The outcome domains were labeled Relationships with Nature, Escape Pressures, Achievement, Autonomy, Reflection on Personal Values, Sharing/Recollection, Risk Taking, and Meeting/Observing Other People.

In the table, mean scores for each outcome domain and for each individual item are given. The reliability coefficient for each domain is also shown. While the outcomes of relationships with nature, escape pressures, achievement, autonomy, reflection on personal values, and sharing/recollection were clearly perceived to add to the respondent's wilderness experience, the outcomes of risktaking and meeting/observing other people were in general perceived neither to add to nor detract from the experience.

Individuals were then grouped, through object cluster analysis, according to their scores on the eight outcome domains. Five recreationist types (groups) using the Rawah Wilderness were identified. Table 2 shows the five types and their mean scores on each outcome domain. Each type is described by the number and proportion of its members in the sample and by a verbal and numerical

7 The BC-TRY system uses a parallel form approach to reliability; the $\mathrm{r}>.40$ is a fairly stringent criterion based upon observations from many studies (Driver, personal communication, n.d.), and items not relating intuitively like a coupling of "feeling frightened" and "having a desire to relax" seldom occur. 
description of the preceived importance to satisfaction of each outcome domain. In general, the outcome domains have been arranged from left to right based on their perceived importance to satisfaction (most to least, respectively). Also, those types with generally more positive scores are at the top of the table and those with lower scores at the bottom.

Looking down the columns of Table 2 indicates the proportion of recreationists in each type, the outcome domains which discriminate among types, and the range of value for each outcome domain. For instance, type five has the most members while type two has the fewest, the escape pressures domain has the least discriminability while meeting/observing other people has the most, and relationships with nature is the most strongly valued outcome while meeting/observing other people is the least valued.

A look across the rows of Table 2 provides a description of the five types. Type 1 might be labeled the positivists based upon their strong positive scores on most domains. This group had the most positive response to six of the eight psychological outcome domains. In many respects this group resembles the traditional wilderness users depicted in the popular literature except that they positively value affiliation with other groups as part of the recreation experience.

Type 2 differs little from Type 1 except for a markedly lower value attached to meeting/observing other people and slightly lower values for the sharing/ recollection and escape pressures domains. Type 2 might be labeled the traditional wilderness recreationist.

Type 3 does not value most of the outcome domains as much as the two previous groups. Members of this type can best be characterized as not valuing risk-taking and valuing relatively highly the sharing/recollection dimension. For the remaining outcomes their responses generally fell in the middle of the distribution.

Type 4 had the lowest mean on the sharing/recollection domain, had a relatively high mean on risk taking, and was fairly neutral about meeting/ observing other people.

The last group of users, Type 5, has generally lower means for the domains than the other groups. Means for this type were the lowest on five of the eight outcome domains. On the other three outcome domains, the values expressed by this type were next to the lowest. None of the outcomes was considered by these people to strongly or most strongly add to their satisfaction.

The 4CAST subroutine of the BC-TRY system was used to further describe the types. Descriptive variables included the number of nights spent in the Rawah Wilderness, the number of total visits to other wilderness areas, age of respondents, size of home community, education level, and annual income. 


\section{TABLE 1}

Eight psychological outcome domains and their respective items identified by cluster analytic techniques of responses from 264 Rawah Wilderness users (summer 1975).

\begin{tabular}{|c|c|c|c|}
\hline $\begin{array}{l}\text { Psychological Outcome } \\
\text { Doma ins and Items }\end{array}$ & $\begin{array}{l}\text { Doma in } \\
\text { Item M }\end{array}$ & $\begin{array}{l}n \text { and } \\
\text { Means }\end{array}$ & $\begin{array}{l}\text { Domain } \\
\text { Relfabifityb }\end{array}$ \\
\hline $\begin{array}{l}\text { Relationships with Nature } \\
\text { Being where things are natural } \\
\text { Gaining a greater appreciation of nature } \\
\text { Discovering something new } \\
\text { The smelis, sights, and sounds of nature } \\
\text { Living in harmony with nature }\end{array}$ & $\begin{array}{l}3.24 \\
3.07 \\
3.01 \\
3.37 \\
2.75\end{array}$ & 3.09 & .87 \\
\hline $\begin{array}{l}\text { Escape Pressures } \\
\text { Getting rejuvenated } \\
\text { Having d chance to relax } \\
\text { Relfeving frustrations } \\
\text { Being away from crowds } \\
\text { Being where it is quiet }\end{array}$ & $\begin{array}{l}2.61 \\
2.92 \\
1.98 \\
3.55 \\
3.39\end{array}$ & 2.89 & .79 \\
\hline $\begin{array}{l}\text { Achievement } \\
\text { Getting a sense of accomplishment } \\
\text { Practicing ski1ls } \\
\text { Developing skifls and abflitties }\end{array}$ & $\begin{array}{l}2.71 \\
2.23 \\
2.64\end{array}$ & 2.46 & .91 \\
\hline $\begin{array}{l}\text { Sensing your endurance and stamina have } \\
\text { Improved } \\
\text { Findfng out what you can do } \\
\text { Challenging nature with your skills } \\
\text { Feeling a sense of conquest after the trip } \\
\text { Doing something not done by everyone }\end{array}$ & $\begin{array}{l}2.66 \\
2.20 \\
2.30 \\
2.41 \\
2.49\end{array}$ & & \\
\hline $\begin{array}{l}\text { Autonomy } \\
\text { Doing things your own way } \\
\text { Feeling free from society's restrictions } \\
\text { Freedom of choice } \\
\text { Being obligated to no one } \\
\text { Traveling where you desire } \\
\text { Being alone }\end{array}$ & $\begin{array}{l}2.15 \\
2.43 \\
2.65 \\
1.81 \\
2.95 \\
2.54\end{array}$ & 2.42 & .83 \\
\hline $\begin{array}{l}\text { Reflection on Personal values } \\
\text { Having a chance to think about you life } \\
\text { Attaining new perspective on life } \\
\text { Contemplating your future } \\
\text { Learning about yourself }\end{array}$ & $\begin{array}{l}2.40 \\
2.25 \\
1.63 \\
2.33\end{array}$ & 2.15 & .84 \\
\hline $\begin{array}{l}\text { Sharing/Recollection } \\
\text { Showing pictures of trip to family and friends } \\
\text { Telling others about trip } \\
\text { Photographing }\end{array}$ & $\begin{array}{l}1.75 \\
1.92 \\
2.03\end{array}$ & 1.90 & .80 \\
\hline $\begin{array}{l}\text { Risk-Taking } \\
\text { Feel ing frightened } \\
\text { Not knowing for sure where you are } \\
\text { Losing your sense of direction } \\
\text { Confronting hazardous obstacles } \\
\text { Taking risks }\end{array}$ & $\begin{array}{r}-0.41 \\
-0.03 \\
-0.40 \\
1.41 \\
0.81\end{array}$ & 0.28 & .82 \\
\hline $\begin{array}{l}\text { Meeting/Observing Other People } \\
\text { Socializing with other parties } \\
\text { Meeting other wilderness users } \\
\text { Chatting with other hikers } \\
\text { Knowing other users are nearby }\end{array}$ & $\begin{array}{r}0.00 \\
0.10 \\
1.20 \\
-1.04\end{array}$ & 0.07 & .83 \\
\hline
\end{tabular}

${ }^{a} A$ 9-point scale was used where +4 equaled most strongly added to satisfaction and -4 equaled most strongly detracted from satisfaction.

BC-TRY uses a parallel form measure of rellability (Tryon and Bailey 1970). 
TABLE 2

Verbal and numberical description of the perceived importance

to satisfaction of each psychological outcome domain for

each of the five types of Rawah Wilderness users identified. . . . . . . .

through object cluster analysis.

\begin{tabular}{|c|c|c|c|c|c|c|c|c|c|c|}
\hline \multirow[t]{2}{*}{ Type } & \multirow[t]{2}{*}{$\begin{array}{l}\text { Nunber of } \\
\text { People }\end{array}$} & \multirow[t]{2}{*}{ Proportion } & \multicolumn{8}{|c|}{ Psychological Outcome Domains } \\
\hline & & & $\begin{array}{c}\text { Relationships } \\
\text { with } \\
\text { Nature }\end{array}$ & $\begin{array}{l}\text { Escape } \\
\text { Pressures }\end{array}$ & Autonoiny & Achievement & $\begin{array}{l}\text { Reflection on } \\
\text { Personal } \\
\text { Values }\end{array}$ & $\begin{array}{c}\text { Sharing/ } \\
\text { Recollection }\end{array}$ & $\begin{array}{c}\text { Risk } \\
\text { Taking }\end{array}$ & $\begin{array}{c}\text { Meeting/ } \\
\text { Observing } \\
\text { Other People }\end{array}$ \\
\hline 1 & 50 & 19 & $\begin{array}{l}\text { Most Strongly } \\
\text { Added } \\
+3.78\end{array}$ & $\begin{array}{c}\text { Most Strongly } \\
\text { Added } \\
+3.62\end{array}$ & $\begin{array}{c}\text { Strongly } \\
\text { Added } \\
+3.38\end{array}$ & $\begin{array}{l}\text { Strongly } \\
\text { Added } \\
+3.36\end{array}$ & $\begin{array}{l}\text { Strongly } \\
\text { Added } \\
+3.24\end{array}$ & $\begin{array}{l}\text { Strongly } \\
\text { Added } \\
+2.69\end{array}$ & $\begin{array}{l}\text { Slightly } \\
\text { Added } \\
+1.17\end{array}$ & $\begin{array}{l}\text { S1 ightly } \\
\text { Added } \\
+1.05\end{array}$ \\
\hline 2 & 27 & 10 & $\begin{array}{l}\text { Most Strongly } \\
\text { Added } \\
+3.57\end{array}$ & $\begin{array}{l}\text { Strongly } \\
\text { Added } \\
+3.30\end{array}$ & $\begin{array}{l}\text { Strongly } \\
\text { Added } \\
+2.86\end{array}$ & $\begin{array}{l}\text { Strongly } \\
\text { Added } \\
+2.90\end{array}$ & $\begin{array}{l}\text { Strongly } \\
\text { Added } \\
+2.57\end{array}$ & $\begin{array}{l}\text { Moderately } \\
\text { Added } \\
+2.25\end{array}$ & $\begin{array}{l}\text { Slightly } \\
\text { Added } \\
+0.51\end{array}$ & $\begin{array}{c}\text { Moderately } \\
\text { Detracted } \\
-2.03\end{array}$ \\
\hline 3 & 44 & 17 & $\begin{array}{l}\text { Strongly } \\
\text { Added } \\
+3.15\end{array}$ & $\begin{array}{l}\text { Strongly } \\
\text { Added } \\
+2.82\end{array}$ & $\begin{array}{l}\text { Moderately } \\
\text { Added } \\
+2.26\end{array}$ & $\begin{array}{l}\text { Strongly } \\
\text { Added } \\
+2.70\end{array}$ & $\begin{array}{c}\text { Moderately } \\
\text { Added } \\
+2.27\end{array}$ & $\begin{array}{c}\text { Strongiy } \\
\text { Added } \\
+2.83\end{array}$ & $\begin{array}{r}\text { Neither } \\
-0.46\end{array}$ & $\begin{array}{c}\text { S1ightly } \\
\text { ndded } \\
+0.78\end{array}$ \\
\hline 4 & 53 & 20 & $\begin{array}{l}\text { Strongly } \\
\text { Added } \\
+3.22\end{array}$ & $\begin{array}{l}\text { Strongly } \\
\text { Added } \\
+3.01\end{array}$ & $\begin{array}{c}\text { Strongly } \\
\text { Added } \\
+2.54\end{array}$ & $\begin{array}{l}\text { Moderately } \\
\text { Added } \\
+2.41\end{array}$ & $\begin{array}{l}\text { Moderately } \\
\text { Added } \\
+2.00\end{array}$ & $\begin{array}{l}\text { Slightly } \\
\text { Added } \\
+1.19\end{array}$ & $\begin{array}{l}\text { Slightly } \\
\text { Added } \\
+0.89\end{array}$ & $\begin{array}{r}\text { Neither } \\
+0.27\end{array}$ \\
\hline 5 & 60 & 23 & $\begin{array}{l}\text { Moderately } \\
\text { Added } \\
+2.29\end{array}$ & $\begin{array}{l}\text { Moderately } \\
\text { Added } \\
+2.21\end{array}$ & $\begin{array}{l}\text { Noderately } \\
\text { Added } \\
+1.54\end{array}$ & $\begin{array}{l}\text { Slightly } \\
\text { Added } \\
+1.29\end{array}$ & $\begin{array}{l}\text { Slightly } \\
\text { Added } \\
+1.03\end{array}$ & $\begin{array}{c}\text { Si ightly } \\
\text { Added } \\
+1.41\end{array}$ & $\begin{array}{r}\text { Neither } \\
-0.27\end{array}$ & $\begin{array}{r}\text { Neither } \\
-0.11\end{array}$ \\
\hline$u^{\mathbf{a}}$ & 30 & 11 & & & & & & & & \\
\hline & & & & 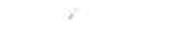 & & & & & & \\
\hline
\end{tabular}

"There were 30 individuals ( 11 percent). that were identified as unique in the sense they were not grouped with any of the types. Within the BC-TRY O-Type subroutine, identification of unique individuals is primarily a function of missing data rather than some "true" uniqueness. 
Only significant relationships $(p \leq .10)$ between descriptor variables and user types are indicated.

The Type 1 recreationist group has the lowest average age (about 24 years), lowest average years of education (about two years of college), and the lowest average annual income (about $\$ 11,000$ ). Many members of this type were students, a fact which explains their age, education, and income in relation to the other types.

The traditional wilderness type (Type 2) had the most years of formal education (college graduates and post-graduates). Type 3 recreationists generally spent more nights in the wilderness and came from larger population centers. Type 4 was characterized by recreationists being relatively inexperienced in wilderness use, having had zero to few previous visits to wilderness areas. Type 5 had an older average age (about 31 years), many years of formal education (college graduates and post-graduates) and high incomes.

\section{Discussion}

The results presented should be considered as illustrative of the types of users of the Rawah Wilderness; they are not necessarily proportionately representative of the users. The sample was drawn from trail registrations which are often not filled out by all visitor parties (Lucas et al. 1971). Also, if one assumes that those registrations that were filled out were done so by party heads, we do not know if the preferences of these persons are the same as the preferences of other members of their party (Jubenville 1971).

Recognizing these limitations of the data and the limitations inherent in cluster analytic procedures, we might see what can be learned about the different types of users and how these kinds of data might be used in planning and management. Because of the limitations,we make no suggestion that one should freely generalize from these data to firm management prescriptions; there is too much yet to learn about wilderness users.

Type 1 exhibits many values consistent with the traditional wilderness user as depicted in the literature. However, the group exhibits less concern about solitude and isolation than we might expect from popular literature descriptions of the traditional user. Also, this group exhibits more concern for discussing their wilderness experiences with others than do most other types of users. Whether or not these young people will carry these preferences into later life we cannot predict.

Type 2, the type we have called the traditional user, is not as prevalent in the Rawah Wilderness as we previously thought. It is possible that this type never was very prevalent and that we had developed unreal expectations about the proportion of traditional users based on our reading of the popular literature 
about quality wilderness experiences. Alternatively, it might have been more prevalent in the past and changing use patterns and norms might have reduced its dominance in the Rawah Wilderness. Independent of either alternative, this type is quite dependent upon the resource base and low levels of area use for its members to gain satisfaction. One might suspect from the scores of this group on the autonomy and meeting/observing other people domains that management actions undertaken off site to regulate use would be accepted, but those undertaken on site would not be desired.

Types 3, 4, and 5 could easily fulfill most of their desires if management focused on meeting the desires of Types 1 and 2 . Type 4 is additionally of interest because they are relative novices to wilderness recreation. It appears that they have pciked up many of the desires of Types 1 and 2, an interest in relationships with nature, excaping pressures, and having freedom of time and movement (autonomy). It is possible that if they have been satisfied with their first wilderness recreation experience they might become members of the traditional group in the future.

This type of information on the pschyological outcomes sought by recreationists and on the types of recreationists pursuing specific activities in specific areas can be useful to planners and managers. Five areas in which this type of information can be used are devising and selecting management objectives, organizing and conducting recreation inventories, selecting management practices, economically valuing the experience and the resource, and developing visitor information programs.

Management objectives might be visualized as statements of the kind and amount of recreation opportunities to be produced (Brown 1977). Many authors have suggested their relevance to recreation planning and management for wilderness and other unique resources (Wagar 1951; Wagar 1964 and 1966; Lime and Stakey 1971; Frissell and Stankey 1972; Lucas 1973; Hendee 1974; Brown et al. 1976; Brown 1977). In writing objectives, information on user preferences for psychological outcomes can be useful for specifying the type of experience and specific psychological outcomes for which opportunities are to be produced. For instance, such information would enable the decision-maker to know whether or not the desired experience has an anti-other-people orientation (Type 2 in the Rawah Wilderness) or some other attribute. Of course, user preferences are not the only kind of information the formulator of objectives might consider, but they can be useful in identifying who wants what.

Such information is also useful for developing recreation resource inventories (Driver and Brown 1978; Brown et al. 1978) and in selecting management practices to achieve specific objectives (Brown 1977). Inventories undertaken to determine where and how to meet user desires can be aided by knowing speifically what the desires represent, i.e., if they are desires for isolation from others, risk taking, or experiencing nature. Different sets of desired outcomes might 
require that different resource, social, or managerial characteristics of the environment be examined in inventories.

In selecting management practices, outcome information is also important. For instance, if managers desire to provide opportunity for achievement of the Type 2 experience in the Rawah Wilderness, they might need to consider regulation of either total use levels or the distribution of use, and then select practices to limit or redistribute use. Also to meet the desires of the Type 2 users for freedom of time and movement, the practices selected to limit or change use would need to be practices which do not compromise freedom of use while a person is in the area.

Economic valuation is an old problem which might be aided by knowledge of the psychological outcomes which users desire. Cicchetti and Smith (1973) had some success in differentially valuing wilderness recreation experiences that varied in the amount of out-group contact which might be experienced. We suppose that if more outcome variables were included in their specification of different experiences, they would have had even more success in differentially valuing experiences. In a limited test of this notion, Miller et al. (1977) using a willingness to pay measure, had success with this technique when valuing deer hunting experiences in Colorado.

Another possible use of these kinds of data is in developing visitor information programs. The data represent one way to segment the market of users and enable development of information programs that focus on different market segments. Developing information about wilderness and other areas that might provide different recreation experiences would provide users better information on where they might go to get the experiences they desire. Wilderness areas vary in what they offer and users differ in what they seek. Matching preferences with offerings should be facilitated with better preference information.

Considerable research is still needed before we can fully use psychological outcome information in wilderness recreation planning and management. More representative samples need to be selected than the one used in this research. A greater array of psychological outcomes (like those mentioned in Footnote 3) might be examined, though some are unlikely to be relevant to wilderness recreation. The experiences desired by recreationists might be correlated with various resource, social, and managerial attributes of the recreation setting and with more specific recreation activities. Meeting these and other research needs would further help to identify the value of this type of preference information for recreation planning and management.

\section{References}

Atkinson, J. 1957. Motivational determinants of risk taking behavior. Psychological Review 64:359-372. 
Brown, P. J. 1977. Information needs for river recreation planning and management. In Proceedings of River Recreation Management and Research Symposium. USDA Forest Service, GTR-NC 28, pp. 193-201.

Brown, P. J.; A. Dyer; and Whaley, R. S. 1973. Recreation research-so what? Journal of Leisure Research 5(1):16-24.

Brown, P. J.; Driver, B. L.; and Stankey, G. H. 1976. Human behavioral science and recreation management. In XVI Int. Union For. Res. Organ. World Congr. Proc., Div. VI, Vienna, Austria, pp. 53-63.

Brown, P. J.; Driver, B. L.; and McConnell, C. 1978. The opportunity spectrum concept in outdoor recreation supply inventories: background and application. In Proceedings of Integrated Renewable Resource Inventories Workshop. USDA Forest Service, GTRRM 55, pp. 73-82.

Brown, P. J.; Hautaluoma, J. E.; and McPhail, S. M. 1977. Colorado deer hunting experiences. Transactions of the North American National Wildlife and Natural Resources Conference, Wildlife Management Institute, Washington, D. C., 42:216-225.

Catton, W. R., Jr. 1969. Motivations of wilderness users. Pulp and Paper Magazine of Canada, pp. 121-126.

Cicchetti, C. J. and Smith, V. K. 1973. Congestion, quality, deterioration, and optimal use: wilderness recreation in the Spanish Peaks Primitive Area. Resources For the Future, Inc., No. 109, Washington, D. C.

Clark, R. N.; Hendee, J. C.; and Campbell, F. L. 1971. Values, behavior, and conflict in modern camping culture. Journal of Leisure Research 3(3):1.43-159.

Driver, B. L. n.d. Personal communication.

Driver, B. L. 1976. Quantification of outdoor recreationists' preferences. In Betty van der Smissen (ed.) Research, camping, and environmental education. Penn. State Series 11. College Park, PA.

Driver, B. L. and Brown, P. J. 1975. A socio-psychological definition of recreation demand, with implications for recreation resource planning. In Assessing Demand for Outdoor Recreation, National Academy of Sciences, Washington, D. C., pD. 62-88

Driver, B. L. and Knopf, R. C. 1976. Temporary escape: one product of sport fisheries management. Fisheries 1(2):21-29.

Driver, B. L. and Tocher, S. R. 1970. Toward a behavioral interpretation of recreational engagements, with implications for planning. In B. L. Driver (ed.) Elements of outdoor recreation planning, University Microfilms, Ann Arbor, Michigan, pp. 9-31.

Driver, B. L. and Brown, P. J. 1978. The opportunity spectrum concept in outdoor recreation supply inventories: an overview. In Proceedings of Integrated Renewable Resource Inventories Workshop. USDA Forest Service, GTR-RM 55, pp. 24-31.

Frissell, S. S. and Stankey, G. H. 1972. Wilderness environmental quality search for social and ecological harmony. Proceedings of the SAF annual conference. Washington, D. C.; Society of American Foresters.

Hautaluoma, J. E. and Brown, P. J. 1978. Attributes of the deer hunting experience: a cluster-analytic study. Journal of Leisure Research 10(4):271-287. 
Hendee, J. C. 1974. A multiple-satisfaction approach to game management. Wildlife Society Bulletin 2(3):104-113.

Hendee, J. C. and Harris, R. W. 1970. Foresters' preceptions of wilderness-user at titudes and preferences. Journal of Forestry 68(12):759-762.

Hendee, J. C.; Catton, W. R.; Marlow, L. D.; and Brockman, C. F. 1968. Wilderness users in the Pacific Northwest: their characteristics, values, and management preferences. Research Paper PNW-61,92 p.

James, G. A. and Schreuder, H. T. 1972. Estimating dispersed recreation use along trails and in generai undeveloped areas with electric-eye counters: some preliminary findings. USDA Forest Service Res. Note SE-181.

Jubenville, A. 1971. A test of differences between wilderness recreation party leaders and party members. Journal of Leisure Research 3(2):116-119.

Knopf, R. C.; Driver, B. L.; and Bassett, J. R. 1973. Motivations for fishing. In Human dimensions in Wildlife programs. J. Hendee and C Schoenfeld (eds.). The Wildilife Management Institute, Washington, D. C. pp. 28-41.

Lawler, E. E. 1973. Motivation in work organizations. Monterey, California: Brooks/ Cole Publishing Co., 231 p.

Lime, D. W. and Stankey, G. H. 1971. Carrying capacity: maintaining outdoor recreation quality. In Recreation Symposium Proceedings. USDA Forest Service, Northeast Forest Experiment Station, pp. 174-184.

Lucas, R. C. 1964. Wilderness perception and use: the example of the Boundary Waters Canoe Area. Natural Resources Journal 3(3):394-411.

Lucas, R. C. 1973. Wilderness: a management framework. Joumal of Soil and Water Conservation 28(4):150-154.

Lucas, R. C.; Schreuder, H. T.; and James, G. A. 1971. Wilderness use estimation: a pilot test of sampling procedures on the Mission Mountains Primitive Area. USDA Forest Service Res. Paper INT-109, 44 p.

Miller, R. R.; Prato, A.; and Young, R. A. 1977. Congestion, success, and the value of Colorado deer hunting experiences. Transactions of the 42nd North American wildlife and natural resources conference. Wildlife Management Institute, Washington, D. C., pp. 129-136.

Peterson, G. L. 1974a. A comparison of the sentiments and perceptions of wilderness managements and canoeists in the BWCA. Journal of Leisure Research 6(3):194-206.

Peterson, G. L. 1974b. Evaluating the quality of the wilderness environment: congruence between perception and aspiration. Environment and Behavior 6(2): 169-193.

Potter, D. R.,; Hendee, J. C.; and Clark, R. N. 1973. Hunting satisfaction: game, guns, or nature. In Human Dimensions in Wildlife Programs, J. Hendee and C. Schoenfeld (eds.). The Wildlife Management Institute, Washington, D. C., pp. 62-71.

Sewell, W. R. and Rostron, J. 1970. Recreational fishing evaluation: a pilot study in Victoria, British Columbia, Department of Fisheries and Forestry, Ottawa, Canada, $133 \mathrm{p}$. 
Shafer, E. L. and Mietz, J. 1969. Aesthetic and emotional experiences rate high with northeast wilderness hikers. Environment and Behavior 1(2):187-197.

Stankey, G. J.; Lucas, R. C.; and Ream, R. 1973. Relationship between hunting success and satisfaction. In Human dimensions in wildlife management, J. Hendee and $\mathrm{C}$. Schoenfeld (eds.). Wildlife Management Institute, Washington, D. C., pp. 77-83.

Tryon, R. C. 1959. Domain sampling formulation of cluster and factor analysis. Psychometrika 24:113-135.

Tryon, R. C. and Bailey, D. E. 1970. Custer analysis. New York: McGraw-Hill Book Co., 347 p.

Wagar, J. A. 1964. The carrying capacity of wildlands for recreation. Forest Science Monograph 7,23 p.

Wagar, J. A. 1966. Quality in outdoor recreation. Trends in Parks and Recreation 3(3): 9-12.

Wagar, J. V. K. 1951. Some major principles in recreation land use planning. Journal of Forestry 49(6):431-435. 